LJILJANA KOLENIĆ

FiLozofski faKULtet SveučILIŠta u OsIJeKu

OsiJek, Hrvatska

kolenic@ffos.hr

https://doi.org/10.17234/9789531755139.14

\title{
ANIMALISTIČKI FRAZEMI U STARIM HRVATSKIM TEKSTOVIMA I U SUVREMENOM HRVATSKOM KNJIŽEVNOM JEZIKU
}

\begin{abstract}
Članak uspoređuje animalističke frazeme u staroj hrvatskoj književnosti s animalističkim frazemima u suvremenom hrvatskom standardnom jeziku. Daju se najčešći oblici animalističkih frazema u starim hrvatskim tekstovima: poredbeni frazemi i sveza pridjeva i imenice. Svaka je tvrdnja oprimjerena animalističkim frazemima iz stare hrvatske književnosti i jednoga staroga hrvatskoga rječnika, Belostenčeva Gazofilacija, jer on ima tronarječnu koncepciju pa su u tom smislu zastupljene sve narječne stilizacije. Najčešće životinje koje se u animalističkim frazemima javljaju jesu one koje se javljaju i u Bibliji jer stara hrvatska književnost, uostalom kao i europska, uzor često traži u biblijskim tekstovima. Frazemi stare hrvatske književnosti prepoznatljivi su i danas premda je moguće da je neka sastavnica zamijenjena bliskoznačnicom, ili da je riječ o različitim narječnim stilizacijama, ili da se frazemske strukture nekada i danas ne podudaraju u cijelosti.
\end{abstract}

Ključne riječi: animalistički frazemi, stari hrvatski tekstovi, suvremeni hrvatski književni jezik, poredbeni frazemi, imenički frazemi

\section{Uvod}

Nema djela ni u staroj ni u novoj hrvatskoj književnosti u kojem se ne pojavljuju životinje. Često se nazivi za životinje pojavljuju i u frazemima. Za ovu analizu izabrano je nekoliko djela starije hrvatske književnosti s nazivom za životinje kao sastavnicom frazema. Cilj je bio istražiti koliko se frazemi sa sastavnicom životinje razlikuju u starim tekstovima od današnjih i koliko to utječe danas na prepoznatljivost frazema. Naime, poznato je da je frazem postojana i prepoznatljiva sveza najmanje dviju riječi s većom ili manjom preobrazbom značenja koja se uklapa u kontekst kao njezin sastavni dio.

Nazivi za životinje nisu uvijek isti u starim tekstovima s onima u suvremenim tekstovima pisanim standardnim hrvatskim jezikom. Stoga se u članku najprije navode nazivi za životinje iz nekih djela stare hrvatske književnosti da se vidi koliko se oni podudaraju ili ne podudaraju sa suvremenima.

Hrvatski petrarkisti Šiško Menčetić i Đore Držić u svojim pjesmama spominju mnoge životinje jer je čest motiv u njihovim pjesmama lov. U petrarkističkim se pjesmama spominju životinje koje su povezane s lovom: hrt, grlica, jelin, lav, košuta, pas, ptice, ribe, sokol, zvir itd. Najčešća životinja je lav s kojim, naravno, pjesnici ne idu u 
lov, nego se lav javlja kao životinja koja lovi druge životinje i progoni ih kao što ljubav „progoni“ petrarkističkoga pjesnika:

zgoni me taj ljubav prid slavni tvoj okol

jakino zvir lav i ptice jur sokol (Šiško Menčetić).

U Šiška Menčetića i Đore Držića uglavnom nema animalističkih frazema što bi se moglo objasniti liričnošću za razliku od epike koja često obiluje takvim frazemima. Kao što je razvidno, nazivi životinje u tih pjesnika podudaraju se sa suvremenim nazivima ako zanemarimo ikavski odraz jata u nekih naziva (zvir, jelin).

U Marulićevoj Juditi (Marulić 1521.) u dvanaesteračkim distisima spominju se: brav, bisan pas, konj, ptić, skot ('stoka, životinja'), sokol, svinja, vol, zvir, zvire.

Pomnjivo je sve nazive za životinje iz Držićeva Dunda Maroja ispisala Zlata Šundalić (Šundalić 2009., 117-123). Prema zapisima Zlate Šundalić, u Dundu Maroju ${ }^{1}$ Marina Držića svoje mjesto u zapisu pronalaze: armilin' ('bijela lasica'), bazilišk ('nestvarna životinja za koju se vjerovalo da truje očima'), buha, čaplja, fadžan ('fazan'), glaine od Indijana ('kokoš'), grinje, grličica, grmuša ('sitna ptica, dračarka'), guja, guska, hobotnica, hrtica, jarebica / jarebičica, kamilionete ('kameleon, vrsta guštera'), kapun / kapunić ('uškopljen pijetao'), kokoš, konj / konjic, kosović, koza, lav, letušte, lisica, mačka, miš, mojemun / mojemuča ('majmun'), narikla (morski pužić), osle / osao, ovca / ovčica, paganjelo ('ptica konopljarka'), papagalo, pas, patka, paun, pijavica, prasac, ptica / ptičica, smudut ('riba lubin'), slavic, spuž ('puž'), srdjela, srdjelica, svinja, tovar, uš, vitelj ('tele'), vuk, zec / zečić, zmaj, zmija, žaba, ždral.

Zlata Šundalić zapisala je i one životinje koje pripadaju predaji, a nisu stvarne, poput baziliška. Kako daje potpuni popis životinja u Držićevu djelu, možemo zabilježiti da se nazivi za neke životinje danas u suvremenom hrvatskom književnom jeziku ne pojavljuju, a neki imaju sličan oblik, ali se u cijelosti ne podudaraju s današnjim nazivima u hrvatskom standardnom jeziku (slavic, spuž, mojemuča) ${ }^{3}$. Osim domaćih naziva javljaju se i nazivi koji su podrijetlom iz drugih jezika, poput latinizama (armilin), talijanizama (kopun), grecizama (kamelionete) i sl.

Matija Antun Reljković preveo je Ezopove i Pilpajeve basne. Kao što je poznato, u basnama su glavni likovi životinje koje se u Reljkovićevu prijevodu zovu: bak ('bik'), deva, divjak ('divlja svinja, vepar'), gavran, grlica, jarac, jare, jarebica, jelin, kopun (pijetao), konj, kukavica, kurjak ('vuk'), lane, lav, lisica, mačka, majmun, magarac, medvid, oroz ('pijetao'), pas, ris, rodo, slavak / slav, srna, stakor, vol, zmija, žaba. U

Autorica zapisuje i dio teksta u kojem se naziv za životinju spominje.

Armilin ili hermelin.

Bila bi zanimljiva analiza tvorbe za pojedine životinje, ali to bi zahtijevalo novi rad. U ovom radu samo naznačujem podjednak odnos sufikasa -ic (konjic, slavic) i -ić (kapunić, zečić) za deminutive muškoga roda. Danas je sufiks -ic neplodan u hrvatskom standardnom jeziku. Za ženske je deminutive i u Dundu Maroju i danas plodan sufiks -ica (srdjelica, jarebičica). 
Reljkovićevu prijevodu javlja se i pokoji turcizam, premda je Matija Antun Reljković bio jezični čistunac, čak je u svojoj Novoj slavonskoj i nimačkoj gramatici (Reljković 1761.) napisao mali rječnik turcizama od 38 riječi za koje drži da bi ih valjalo odbaciti i daje domaće riječi kao zamjene za navedene turcizme. No, u Slavoniji u 18. stoljeću nisu se turcizmi mogli u potpunosti odbaciti pa ih nalazimo i u Reljkovićevu prijevodu Ezopovih basni, poput kurjak, oroz.

U Mažuranićevu spjevu Smrt Smail-age Čengića također se u svim pjevanjima pojavljuju životinje: arslan ('lav'), bik, galeb, guja, golub, jaganjac, jagnje, lav, lastavica, miš, ris, oro, pijetao, vuk itd.

U staroj su hrvatskoj književnosti česti molitvenici. Osječki studenti pod vodstvom Zlate Šundalić iz molitvenika Bogoljupstvo na poštenje svetoga Franceška Saverije Antuna Kanižlića (1759.) izdvojili su ove životinje: crv / crvak, goved, jaganjac, konj, kokoš, lav, medvid, ptičica, rak, riba, stado, zmaj", zmija, zvirad, živina.

Usporedbom naziva za životinje u staroj hrvatskoj književnosti i naziva danas možemo zaključiti:

1. Isti nazivi u starim tekstovima i danas: lav, svinja, lisica, pas, konj, vol, sokol, jarac, grlica, kukavica, gavran, srna, pijetao, miš, vuk, lane, bik, majmun, žaba, jarebica itd.

2. Isti nazivi samo s određenom fonološkom promjenom (odraz jata nije ijekavski kao u suvremenom hrvatskom književnom jeziku, stezanje vokala, redukcije konsonanata i sl.): medvid, jelin, zvir, oro, tić itd.

3. Različita tvorba u odnosu na hrvatski književni jezik: zvire, slavak, slav, jaganjac. U ovaj je popis uvršten i jaganjac, premda je taj naziv živ u tekstovima nabožne tematike: Jaganjac Božji. Držimo da je takav oblik danas arhaičan, a poznato je da se u crkvenim tekstovima čuvaju stariji oblici i nazivi zbog čestoga ponavljanja (frekventnosti) tih naziva.

4. Različiti nazivi karakteristični ili za narječnu stilizaciju ili za zemljopisni prostor, a različiti od suvremenoga hrvatskoga književnoga jezika: čvarljak ('čvorak'), arslan ('lav'), kurjak ('vuk'), bak ('bik'), oroz ('pijetao'), praz ('ovca').

5. U starim se tekstovima pojavljuju i nestvarne životinje poput zmaja i baziliška pa su i one uvrštene u popis.

Uglavnom se nazivi za životinje podudaraju u starim tekstovima i danas u suvremenom hrvatskom književnom jeziku ili se takvi nazivi čuju u hrvatskim narodnim govorima. Pri tom je nebitno je li riječ izvorna domaća ili podrijetlom tuđica poput kurjaka, arslana, oroza i sl.

$\overline{4}$ U popis je uvršten i zmaj premda je on mitska nestvarna životinja. U starim tekstovima zmaj se često, osobito u frazemima, zamjenjuje sa zmija pa je i zbog toga uvršten u popis. 
U mnogim djelima i u staroj i u novoj hrvatskoj književnosti nazivi za životinje sastavnicom su frazema. Dakako, nazivi za životinje javljaju se kao natuknice ili u tumačenjima starih hrvatskih rječnika. I u starim hrvatskim rječnicima nazivi za životinje dijelom su hrvatske frazeologije.

Za analizu izabrali smo nekoliko reprezentativnih djela stare hrvatske književnosti i jednoga staroga hrvatskoga rječnika, Belostenčeva. U izboru smo nastojali da budu djela iz različitih hrvatskih stilizacija. To su djela:

Marko Marulić: Judita (1521.)

Marin Držić: Dundo Maroje (16. st.)

Andrija Kačić Miošić: Razgovor ugodni naroda slovinskoga (1756.)

Antun Kanižlić: Bogoljubstvo na poštenje svetoga Franceška Savarije (1759.)

Vid Došen: Aždaja sedmoglava (1768.)

Ivan Mažuranić: Smrt Smail-age Čengića (1846.)

Kao što je već rečeno, građa je ekscerpirana i iz jednoga rječnika:

Ivan Belostenec: Gazofilacij (1740.)

Animalistička je frazeologija u ovom radu podijeljena na poredbene frazeme, imeničke frazeme, glagolske frazeme.

Posebno su u ovom dijelu zapisane i neke poslovice i krilatice u kojima se pojavljuju životinje da bismo ilustrirali koliko se često životinje pojavljuju u postojanim svezama čije se značenje ne izvodi iz značenja pojedinačnih sastavnica.

\section{Animalističke poslovice i krilatice}

Poslovice koje sadrže kao sastavnicu naziv za životinju ili pak dio životinjskoga tijela nalazimo i u starih hrvatskih pisaca i u starim hrvatskim rječnicima. Tako je poznato da Ivan Belostenec u svom Gazofilaciju ima cijele poslovice, često u stihu, uz pojedine natuknice, a neke od tih poslovica kao sastavnicu imaju imenicu koja znači životinju. Uz neke je pak natuknice zapisivao i krilatice i frazeme. Navodimo neke poslovice, krilatice i frazeme za ilustraciju i natuknicu pod kojom možemo poslovicu naći u hrvatsko-latinskom dijelu rječnika, uz napomenu da uglavnom uz takve poslovice u Gazofilaciju stoji prov. da bi se pojasnilo da je riječ o poslovici:

S. v. Maček, mačka: Hiža na glasu, a mačka gladne.

Što mačka rodi, vse miše lovi.

Kupovati mačku v mehu.

S. v. Miš: Teško je mišu z mačkom.

S. v. Riba: Riba iz glave smerdi.

S. v. Sojka: Lepo perje ima sojka / Akoprem hman je pojka.

S. v. Proso: Luda pamet ka ne seje prosa / Bojeći se vrabcev nosa.

S. v. Oslovac: Gospodar ak nema neg dinar ali je gospodar / oslovac ak ima zlat pokrovac, ali je oslovac. 
S. v. Osel: osel na klupi, diak kruto tupi. Z kem se paris cupi lupi / osel vsigde i na kljupi.

S. v. Kauran, krompač (D.) vran, gavran: Vrana vraniću oko ne izbija. Kauran kauranu oči ne izbada.

Ovi primjeri pokazuju da su stari hrvatski rječnici zapisivali poslovice (pa i one u kojima se javljaju životinje), a Belostenec je često takve poslovice slagao u stihove s rimom. Pored toga, možemo reći da u Belostenčevu Gazofilaciju nalazimo dosta animalističkih frazema. Navedene poslovice, krilatice i frazeme iz Gazofilacija prepoznajemo i danas premda je književni jezik Belostenčeva rječnika tronarječne stilizacije.

Animalističke poslovice nalazimo i u drugim djelima stare i nove hrvatske književnosti, a ovom prigodom izdvajamo neke iz Dunda Maroja Marina Držića. Marin Držić u Dundu Maroju varira istu poslovicu s nazivima životinja da bi naglasio kako se (loša) ćud (ljudska) ne mijenja. Zapravo varira poslovicu koja se javlja u starim i novim tekstovima, a glasi: Što mačka rodi, sve lovi miševe. U Dundu Maroju tu poslovicu nalazimo u nekoliko varijanata, ne samo s mačkom, nego is bjestijom, lisicom, hrticom, zmijom.

Tko je bjestija, bjestija će i umrijet.

Sve što lisica leže, sve liha.

A sve što se od mačke rodi, sve miše lovi.

Što hrtica koti, sve zeca tjera.

A zmije što rađaju, sve to prokleto sjeme jadom meće.

Marin Držić osim poslovica sa značenjem ,ćud se ljudska ne mijenja“ ima i druge s nazivima za životinje. Primjerice poslovica koja znači da se ne mogu složiti prirodni neprijatelji glasi u Dundu Maroju: Među lisicom i hrtom nije ugođaja. Poslovica koja znači da se mirnoćom i nenametljivošću mnogo više postiže u Dundu Maroju glasi: Plašilo ovcu tjera, tihoćina vuka stiže. Krilatica Ne će mačka larda! je usklik koji znači da mačka hoće jesti slaninu, odnosno da se svatko može pridobiti dobrim mamcem.

Poslovica Što mačka rodi, sve lovi miševe česta je u hrvatskim tekstovima pa ju nalazimo osim u Dundu Maroju Marina Držića i u drugih pisaca, primjerice u stihovima Vida Došena u Aždaji sedmoglavoj ili u Belostenčevu rječniku pod natuknicom maček, mačka. Dakako, poslovica je napisana hrvatskim književnim jezikom vremena u kojem pisac stvara.

Vid Došen u Aždaji sedmoglavoj, primjerice, često umeće poslovice i frazeme u stihu. Te su poslovice i frazemi poznati, ali ih nismo naučili čuti u stihovima premda je poznato da se i mnoge poslovice i frazemi često pojavljuju u sročnim stihovima. Navodimo iz Došenove Aždaje sedmoglave frazeme u stihovima i rimi:

Tko se miša s mekinami

ručak biva krmačami.

Ta je poslovica poznata kao 'tko se miješa s mekinjama, pojest će ga svinje'. 


\section{Animalistički frazemi}

\section{a) Poredbeni frazemi}

Poredbeni animalistički frazemi jesu oni koji neku osobinu, djelovanje i sl. uspoređuju s osobinom određene životinje. Iz korpusa se može zaključiti da je u poredbenim frazemima ovca jedna od najčešćih životinja (odnosno nazivi koji su se u određenom djelu rabili za ovcu). To se može objasniti činjenicom da je Biblija u staroj hrvatskoj književnosti imala nezaobilaznu ulogu i da su biblijske prispodobe i biblijske misli prožele ne samo hrvatsku nego i europsku književnost. Poznato je da se ovca, odnosno i janje često spominju u Bibliji. Izdvojit ću samo neke poredbene frazeme s ovcom (prazom, bravom) kao sastavnicom iz korpusa stare hrvatske književnosti: Kako ovca v zakolen'ju / takovi smo svi v mišlen'ju (iz hrvatske srednjovjekovne književnosti), Obal kako praz ki još ni strižen bil (Judita Marka Marulića), Otklati glavu kako bravu (Judita Marka Marulića), O da bi ja njega!... Makar i brez novca / jer je svrh tog svega miran kao ovca. (Sveta Rožalija Antuna Kanižlića), A mjesec bi vitorog te gledo sa zapada ispred zvijezdah sjajnijeh, ko prevodnik ispred stada ovan (Smrt Smail-age Čengića Ivana Mažuranića). Osim ovce, česta je životinja u frazemima i zmija (guja). I ta je životinja česta u biblijskim tekstovima, a javlja se u frazemima stare hrvatske književnosti kao životinja koja nosi negativna obilježja: šaren kako i zmija, vlači se tiho kako i zmija (Dundo Maroje Marina Držića), Pisnu Ture kano guja ljuta (Smrt Smail-age Čengića Ivana Mažuranića), Tad on njegda ljući guje ljute mal'ne zeca plašljiviji kleca (Smrt Smail-age Čengića Ivana Mažuranića). I druge su životinje sastavnicom poredbenih frazema u starim hrvatskim tekstovima. Primjerice pas (kakono bisan pas), kokoš (kako kokoš slipa), uš (mizer kako uš) itd.

- Poredbeni frazemi prema vrsti riječi kojom tumačimo frazem

Uglavnom se poredbeni frazemi s obzirom na vrstu riječi kojom ih tumačimo dijele na pridjevne i na glagolske, a rjeđe i na priložne (odnosno tumačimo ih priložnom oznakom u rečenici).

Pridjevni su oni koji se mogu protumačiti pridjevom. Takvi su primjerice: obal kako praz ('obao, debeo'), miran kao ovca ('miran'), smerdeči kot kozel ('smrdljiv'). U takvim frazemima pridjev koji je sastavnicom frazema uglavnom se uspoređuje s određenom životinjom za koju se drži da ima takvu osobinu ili joj se (neopravdano) takva osobina pridružuje.

Glagolski su oni koji se mogu protumačiti glagolom. Takvi su, primjerice: otklati glavu kako bravu ('zaklati'), riknuti ko bik ('riknuti'). U takvim frazemima glagol koji je sastavnicom frazema uglavnom se uspoređuje s određenom životinjom koja se povezuje svojim djelovanjem ili djelovanjem ljudi prema njoj s djelovanjem glagola.

Priložni frazemi tumače se prilogom. To su često frazemi dvodijelne strukture u kojima je izostala sastavnica koja se uspoređuje. Sastoje se od poredbenoga veznika i naziva za životinju (može doći i koji dodatak). Takvi su frazemi kao miš u posijama ('nevidljivo, skriveno'), kakono bisan pas ('bijesno'), kako skot ('životinjski'), ko ovan prevodnik ('predvodnički, kao vođa'), kano guja ljuta ('ljutito'). 
- Poredbeni frazemi s obzirom na stupanj komparacije

S obzirom na stupanj komparacije poredbene smo frazeme podijelili na prvi i drugi stupanj komparacije. Tu smo razliku uveli jer držimo da je poredbeni frazem onaj koji je povezan poredbenim veznikom, dakle koji uspoređuje sličnost pojmova, ali i onaj koji govori o stupnju te sličnosti.

- Prvi stupanj komparacije

Poredbeni frazemi prvoga stupnja komparacije povezani su u našem popisu veznicima kao, ko, kako, kot, kakono, kaono, kano, kanoti, kakonoti, jak, jako. Zanimljivo da je danas u takvim frazemima uglavnom poredbeni veznik kao u hrvatskom standardu, a u dijalektima se može čuti još pokoji. ${ }^{5}$ No u pojedinim slavenskim jezicima zastupljena je većina veznika iz našega popisa (v. Fink Arsovski et al.). Poredbeni animalistički frazemi iz starih tekstova su, primjerice: obal kako praz, riknuti ko bik, smerdeči kot kozel, kuka kano kukavica itd.

Poredbeni animalistički frazemi u starim hrvatskim tekstovima na prvom stupnju komparacije imaju često strukturu':

Pridjevni frazemi: pridjev + kao (ko, kako, kakono i sl.) + imenica (naziv životinje): obal kako praz.

Glagolski frazemi: glagol + kao (ko, kako, kakono i sl.) + imenica (naziv životinje): riknuti ko bik, govoriti kako papagali, kukati kano kukavica.

Priložni frazemi: kao (ko, kako, kakono i sl.) + imenica (naziv životinje): kakono bisan pas.

Animalistički poredbeni frazemi na prvom stupnju komparacije česti su u starim hrvatskim tekstovima, ali i u novima.

- Drugi stupanj komparacije

Poredbeni frazemi drugoga stupnja komparacije govore da su neke osobine izražene jače nego kod životinje koja je po toj osobini poznata. Poredbeni frazemi drugoga stupnja komparacije također mogu biti pridjevni, glagolski, priložni.

Ti frazemi nemaju poredbeni veznik kao, nego najčešće nego, ali mogu biti i s prijedlogom od kao sastavnicom, pa i bez prijedloga. Bitno je da je u takvim svezama jedna sastavnica komparativ.

Pridjevni animalistički frazemi drugoga stupnja komparacije često imaju strukturu:

Pridjev u komparativu + imenica (naziv životinje) u genitivu: ljući guje.

Pridjev u komparativu + od + imenica (naziv životinje) u genitivu: brži od zeca.

$5 \quad$ V. primjerice poredbene veznike u crikveničkom govoru u radu Barbare Kovačević i Martine Bašić (Kovačević i Bašić 2012: 358).

6 O strukturi poredbenih frazema v. Menac 2007: 39-41. 
Premda smo u korpusu stare hrvatske književnosti našli više glagolskih frazema drugoga stupnja komparacije, ovdje navodimo primjer samo jednoga iz našega korpusa animalističkih frazema sa strukturom:

Glagol + prilog (komparativ) + nego + imenička sintagma u nominativu: zaspati gori nego morski medvid.

\section{b) Frazemi sa strukturom pridjev + imenica}

Frazemi sa strukturom pridjev + imenica često znače zapravo metaforu neke ljudske osobine, pa pridjev samo govori o kojoj je osobini riječ ili pojačava značenje osobine koja se toj životinji pripisuje. Takvi su frazemi, primjerice, bila vrana ('neobičan, koji se razlikuje od drugih'), krotko jagnje ('skromnost'), ljuta zmija ('zlo, zloća'), svinja jedna ('pokvarenjak'), pas jedan ('bezobraznik, pokvarenjak'), mrcina lina ('ljenčina'), tihi jaganjac ('krotkost') i sl. Sintagme ljuta zmija i ljuta zvirad u Razgovoru ugodnomu mogu značiti i hrabar junak kao u stihovima: Vrsta svaka ljuti zmija / starišine svoje štuje / dal od ljudi kad odbigneš / zvirad ljutu tad pristigneš. Zanimljivo je da Andriji Kačiću Miošiću ljuti zmaj, ljuta zmija i ljuta zvirad može imati sasvim različita značenja: uobičajeno značenje ('zlo') i neuobičajeno ('junak'). U tu skupinu imeničkih frazema možemo uvrstiti i frazeme koji umjesto pridjeva imaju prijedlog od + imenicu (naziv za životinju) kao što je to primjer u rečenici iz Dunda Maroja: Ovdje trjeba učinit srce od lava, a obraz od zle žene. Srce od lava je zapravo isti frazem koji se u staroj književnosti javlja i kao lavsko srce, a znači 'hrabrost'. Suvremeni ekvivalent toga frazema jest lavlje srce, dakle umjesto prijedloga od i imenice u genitivu (od lava), javlja se posvojni pridjev (lavlji). O uporabi prijedloga od i genitiva u suvremenom standardu ovom prigodom ne ćemo pisati budući da je riječ o animalističkim frazemima u starim tekstovima, ali i novi frazemi ne podliježu uvijek pravilima koja propisuje standardna sintaksa.

Imenički animalistički frazemi sa strukturom pridjev + imenica često su skraćeni poredbeni frazemi pa primjerice ljuta zmija često znači 'ljut kao zmija', ljuti ris 'ljut kao ris', mrcina lina znači 'lijen kao mrcina' itd. Neki imenički frazemi ne mogu se protumačiti na taj način. To su frazemi tipa: sivi soko, konjic zelenko itd. Takve postojane sveze koje se često javljaju u književnosti također smo uvrstili u frazeme jer sadrže osobine frazema: najmanje dvije riječi, postojana sveza, preobrazba značenja manjega opsega. Sivi soko ili konjic zelenko doista nemaju uvijek veliku značenjsku preobrazbu, ali imaju ipak određenu. Primjerice sivi soko znači 'sokol', ali i 'ptica općenito koja leti visoko' pa ima preobrazbu značenja jer se često u starim tekstovima odnosi na ljude koji imaju velike (visoke) kvalitete, kao u stihovima Andrije Kačića Miošića u Razgovoru ugodnomu: gaji ona sivoga sokola / po imenu kralja Tješimira. Odnosno: pa od njega su izašli Bilići / u Cetini sivi sokolići.

Konjic zelenko znači 'konj općenito', ali jedna je od sastavnica ipak doživjela značenjsku preobrazbu jer konjic zelenko znači ‘bilo koji konj', dakle i bilo koje boje, na primjer stih iz Razgovora ugodnoga Andrije Kačića Miošića: Kamo li ti tvoj konjic zelenko? 
Frazemi sa strukturom pridjev + imenica tipa sivi soko i konjic zelenko obično se javljaju u djelima koja svoj uzor nalaze u narodnom pjesništvu. Riječ je o tzv. ukrasnim pridjevima uz neke imenice. To je tip sveza poput sinje more, ravno polje, zelen bor, studena vodica.$^{7}$ I nazivi za životinje javljaju se s određenim stalnim pridjevima u staroj hrvatskoj književnosti. Često su takve sveze s poretkom imenica + pridjev što je stilski obilježen red riječi, čest u pjesništvu. Izdvojit ćemo neke frazeme koji su sastavljeni od stalnoga pridjeva i imenice (imenice i pridjeva) iz našega korpusa prema nazivu za životinju. Takve su sveze, primjerice, konj (konjic) zelenko (Kamo li ti tvoj konjic zelenko, Razgovor Andrije Kačića Miošića), ljuti lav (Nisu gore za te, neg za ljute lave; / tvoj stan dvor jest, da te svi ljube i slave, Rožalija Antuna Kanižlića), sivi soko (sokolić) (pa od njega su izašli Bilići / u Cetini sivi sokolići, Razgovor Andrije Kačića Miošića) itd.

Poznato je da nazivanje ljudi životinjama zvuči često uvrjedljivo. Tako broj jedan služi samo za pojačanje (jedan je intenzifikator u takvim svezama), a kako se jedan javlja u svezi dviju riječi od kojih je jedna naziv za životinju, također možemo govoriti o animalističkom frazemu. Takve frazeme niže stilske razine sa strukturom naziv životinje + jedan nalazimo i u staroj hrvatskoj književnosti. U Dundu Maroju čitamo: Grubiša, gori hodi, svinjo jedna. U molitveniku iz 18. stoljeća (Bogoljubstvo) čovjeku se obraća kao jednom crvku (crvu): Procini, takojer, koliko si puta, ti jedan crvak, veličanstvo Božje pogrdio.

\section{Usporedba s frazemima u suvremenom hrvatskom standardnom jeziku}

Nazivi za životinje nisu uvijek isti u starim tekstovima i u hrvatskom standardnom jeziku, primjerice u starim tekstovima nalazimo: praz, brav, sokolić i sl. Ponekad su se nazivi za životinje, koji danas nisu u hrvatskom standardnom jeziku, zadržali u dijalektima pa su prepoznatljivi u narodnim govorima. U starim tekstovima nalazimo često i mitsku životinju zmaja pa je i zmaj uvršten u ovaj popis. Dakako, riječ je o metodološkom pitanju: treba li zmaja uvrstiti u popis životinja. Budući da je riječ o frazemima u kojima se često zmaj može zamijeniti sa zmija, držimo da ga je opravdano uvrstiti u popis životinja u frazemima. Naravno da bi prirodne znanosti mogle na takav pristup dati ozbiljan prigovor, ali u starim se tekstovima zmaj doživljava kao životinja. Glede baziliška, također nestvarne životinje, valja naglasiti da ne bi trebao biti uvršten u ovaj pregled budući da se, koliko nam je poznato, ne javlja ni u jednom frazemu.

Usporedbom animalističkih frazema u starim tekstovima i onih u suvremenim tekstovima mogu se izdvojiti određeni zaključci.

I takve sveze držimo frazemima jer su postojane i jer je u njima došlo do određene značenjske preobrazbe, ali budući da su tema rada animalistički frazemi, ne ćemo se ovom prigodom zadržavati na tim primjerima. 
a) Frazemi sa strukturom pridjev + imenica po uzoru na narodno pjesništvo

Riječ je o ustaljenim svezama pridjeva i imenice često bez neke veće značenjske preobrazbe poput sivi soko(l), mrki vuk, ljuti zmaj, ljuta zmija / guja, zvirad ljuta, ljuti lav, ljuti ris. Te su sveze uvrštene u frazeme jer su postojane sveze dviju (punoznačnih) riječi, ali s često manjom preobrazbom značenja. Njih tumačimo imenicom pa možemo reći da su imenički frazemi. Takvi frazemi mogu se i danas pojaviti, ali su danas snažno stilski obilježeni.

b) Zamjena neke sastavnice ekvivalentom

Frazeme u starim hrvatskim tekstovima danas prepoznajemo, ali zbog protekloga vremena, jezičnih promjena koje se prirodno događaju u vremenu i prostoru, ti se frazemi javljaju u obliku koji se u cijelosti ne podudara s onima u suvremenom hrvatskom (standardnom) jeziku. Riječ je o ekvivalentima frazema. Jedan od mogućih ekvivalenata jest i onaj kada se zamijeni jedna sastavnica kontaktnim sinonimom, riječi slična značenja i sl. Također su česti ekvivalenti frazema zbog različite tvorbe riječi.

Primjerice frazem othraniti zmiju u njedrima nalazimo u Razgovoru ugodnomu Andrije Kačića Miošića kao frazem odraniti zmaja u nedarcu. U tom frazemu pored nepostojanja fonema $h$ u glagolu odraniti bilježimo i deminutiv imenice njedro. Suvremeni frazem imenicu njedro obično ima u lokativu množine (u njedrima), a u Razgovoru ugodnomu Andrije Kačića Miošića ona je u lokativu jednine s tvorbom -arce za umanjenice. Životinja je u Razgovoru zmaj, a u suvremenom hrvatskom standardnom jeziku uglavnom zmija.

Frazem bacati bisere pred svinje ima svoj ekvivalent u Došenovoj Aždaji: prid krmka biser sipati. Imenica svinja zamijenjena je bliskoznačnicom krmak, a imenica biser javlja se u jednini. Glagol je u tom frazemu u Vida Došena sipati, a u suvremenom frazemu bacati.

Frazem pjevati kao slavuj u Belostenčevu rječniku glasi popevam kot slavič. Glagol pjevati zapisan je u kajkavskoj inačici popevati, a ptica slavuj ima tvorbu od imenice slav i sufiksa za umanjenicu -ič, slavič. valja reći da je ta ptičica u hrvatskoj književnosti vrlo zastupljena, primjerice kupanje slavića u Kanižlićevoj Rožaliji, a često se javlja upravo s deminutivnom tvorbom poput slavić (slavič), slavak ili s nultim tvorbenim sufiksom, slav.

Frazem u Belostenčevu rječniku spim kot zajec ima istu strukturu kao i frazem iz književnoga jezika spavam kao zec i znači ‘spavati nemirnim isprekidanim snom'. U tom je frazemu samo narječna stilizacija kajkavska, spim / spavam, kao / kot / zec / za$j e c$, a frazem sadrži istu strukturu i iste sastavnice.

Svi navedeni frazemi imaju isto značenje u starim tekstovima i danas.

c) Veznici u poredbenim frazemima

U usporedbi sa suvremenim stanjem, možemo u prvom redu primijetiti da poredbeni veznici ne moraju i često nisu isti kao i danas. U poredbenim frazemima na prvom stupnju komparacije veznik može biti: kao, ko, kako, kot, kakono, kaono, kano, kanoti, 
kakonoti, kanda, jak, jako. Primjerice jak kakono lav, smerdeči kot kozel, kuka kano kukavica. Kao što je već rečeno, neke od navedenih porebenih veznika nalazimo i danas u hrvatskim narodnim govorima, ali i u drugim slavenskim jezicima (v. Hrvatsko-slavenski rječnik poredbenih frazema Željke Fink Arsovski et. al., 2006.).

d) Struktura frazema

Strukture frazema nisu uvijek iste u prošlosti i danas. Primjerice poredbeni frazemi u starim tekstovima na drugom stupnju komparacije mogu imati strukturu komparativ pridjeva + imenica u genitivu (plašljiviji zeca, ljući guje), a u suvremenim frazeološkim rječnicima nalazimo komparativ pridjeva + prijedlog od + imenica u genitivu (plašljiviji od zeca, ljući od guje).

e) Životinje koje služe za usporedbu u poredbenim frazemima

U poredbenim frazemima često su iste životinje u pridjevnih i glagolskih frazema u starim tekstovima i danas, poput miran kako ovca, kuka kano kukavica, plašljiviji zeca. Nalazimo i životinje koje danas nisu tako uobičajene kada se želi usporediti neka ljudska osobina sa životinjskom. Primjerice frazem iz Marulićeve Judite jak kakono lav uspoređuje snagu, jačinu s lavom. Danas bi bilo u hrvatskom jeziku običnije jak kao bik. Poredbeni frazem koji znači da je što jako šareno u Belostenčevu je rječniku šarovito kot mačkine oči , a u Držićevu Dundu Maroju je šaren kao zmija. Danas je obično šaren kao papiga.

Frazem obal kako praz (ki još ni strižen bil) u značenju 'debeo' javlja se u Marulićevoj Juditi. Danas bismo obično izabrali svinju kao životinju koju obilježuje debljina, a obal bismo zamijenili s debeo.

Poredbeni frazem iz Belostenčeva rječnika smerdeči kot kozel danas ima drukčiju strukturu i glasi smrdi kao tvor. Umjesto strukture pridjev + poredbeni veznik kot + imenica u nominativu ( $k o z e l$ ) danas ima strukturu: glagol + porebeni veznik kao + imenica u nominativu (tvor). Većina slavenskih jezika osobinu neugodnoga mirisa uspoređuje s tvorom. No, u Hrvatsko-slavenskom rječniku poredbenih frazema (Fink Arsovski et al. 2006.) vidimo da se u ruskom poredbenom frazemu spominje kozel u frazemu koji znači neugodno mirisati, isto kao u Belostenčevu rječniku. U Došenovoj Aždaji nalazi se frazem kako kokoš slipa. U Hrvatsko-slavenskom rječniku poredbenih frazema (Fink Arsovski et al. 2006.) vidimo da se danas uobičajeno u hrvatskom jeziku koristi kao ćorava kokoš. No u istom rječniku razvidno je da većina slavenskih jezika (slovenski, slovački, ukrajinski) nema turcizam ćorav, nego upravo slijep u istovrijednom frazemu, dakle isto kao što to ima Vid Došen u Aždaji sedmoglavoj.

f) Pridjevi kao intenzifikatori uz naziv za životinju

Pridjevi koji se često javljaju uz naziv za životinju u starim tekstovima (i u usmenom pjesništvu) jesu: ljut (ljuti ris, ljuta guja, ljuta zmija, ljuti zmaj, ljuti lav, ljuti bik, ljuta zvirad). Pridjev ljut ispred imenice - naziva za životinju često služi samo za pojačanje osobine koja se pridaje životinji: ljutitost, bijes, opasnost, razjarenost. Danas se takve sveze mogu čuti kao stilski obilježene. 


\section{Zaključak}

Da bismo mogli govoriti o frazemu moraju se ispuniti temeljni uvjeti: mora se sastojati od najmanje dviju riječi postojane i prepoznatljive sveze s djelomičnom ili potpunom preobrazbom značenja. Ako u staroj hrvatskoj književnosti ne možemo odrediti je li što frazem ili nije, moramo se uvjeriti da se sveza s preobrazbom značenja javlja u više djela.

U staroj hrvatskoj književnosti ponekad prepoznajemo strukturu, ali se razlikuju sastavnice (obal kako praz - okrugao / debeo kao svinja) ili se razlikuje struktura, a iste su sastavnice (plašljiviji zeca - plašljiviji od zeca), ili se djelomice razlikuju i struktura i sastavnice, ali je sveza prepoznatljiva (Tko se miša s mekinami / ručak biva krmačami - Tko se miješa s mekinjama, pojest će ga svinje).

$\mathrm{U}$ starim se tekstovima najčešć javljaju u frazeologiji lavovi, ovce (ovca, ovan, praz, brav), janjci, vukovi, sokoli, zmije, mačke. Frazeme prepoznajemo i danas. Većinu životinja u animalističkim frazemima stare hrvatske književnosti prepoznajemo iz biblijskih prispodoba.

Frazemi koji su u ovom radu navedeni prepoznatljivi su, ali se od suvremenih (standardnih) razlikuju zamjenom koje punoznačnice ili nepunoznačnice, narječnom stilizacijom, pa i različitom strukturom.

\section{LITERATURA}

Andrija Kačić Miošić / Razgovor ugodni naroda slovinskoga. Matija Antun Reljković / Satir iliti divji čovik. Priredio Josip Vončina. 1988. Zagreb: Sveučilišna naklada Liber.

Bunk, Ana; Opašić, Maja. 2010. Prilog kontrastivnoj analizi frazema sa zoonimskom sastavnicom u hrvatskome i češkome jeziku. Rasprave Instituta za hrvatski jezik i jezikoslovlje. 36(2): 237-250.

Došen, Vid. 1768. Aždaja sedmoglava. Zagreb.

Kanižlić, Antun. 2013. Bogoljubstvo na poštenje svetoga Franceška Savarije. Pripremili studenti izbornoga kolegija Molitvenici i priredila i dio pogovora napisala prof. Zlata Šundalić Osijek: Filozofski fakultet.

Kanižlić, Antun. 2010. Primogući i srce nadvladajući uzroci. Pretisak iz 1760. godine s usporednom transkripcijom. Pregledala i dio predgovora napisala Zlata Šundalić. Osijek: Filozofski fakultet.

Kolenić, Ljiljana. 1998. Riječ o riječima. Iz hrvatske leksikologije i frazeologije 17. i 18. stoljeća. Osijek: Pedagoški fakultet Sveučilišta J. J. Strossmayera.

Kolenić, Ljiljana. 2006. Riječi u svezama. Povijest hrvatske frazeologije. Osijek: Ogranak Matice hrvatske u Osijeku.

Kovačević, Barbara; Bašić, Martina. 2012. Crikvenički poredbeni frazemi i njihovi ekvivalenti u hrvatskome jezičnom standardu. Rasprave Instituta za hrvatski jezik i jezikoslovlje. 38(2): 357-384. 
Menac, Antica. 2007. Hrvatska frazeologija. Zagreb: Knjigra.

Menac-Mihalić, Mira. 2007. O nekim hrvatskim dijalektnim frazemima sa zoonimskom sastavnicom. U: Kulturni bestijarij. Zagreb: Institut za etnologiju i folkloristiku - Hrvatska sveučilišna naklada. 389-400.

Mažuranić, Ivan. 1846. Smrt Smail-age Čengića. Zagreb.

Moguš, Milan. 2001. Rječnik Mažuranićeve pjesni Smrt Smail-age Čengića. U: Ivan Mažuranić Smrt Smail-age Čengića. Zagreb: HAZU. 125-251.

Reljković, Matija Antun. 1767. Nova slavonska i nimačka gramatika. Zagreb.

Ribarova, Slavomira; Vidović Bolt, Ivana. 2005. Biblijski frazemi sa zoonimskom sastavnicom u hrvatskom, češkom i poljskom jeziku. U: Semantika prirodnog jezika i metajezik semantike. Zagreb - Split: Hrvatsko društvo za primijenjenu lingvistiku. 643-653.

Šundalić, Zlata. 2009. Životinja i Vidra. O životinjskom svijetu u djelu Marina Držića Vidre. Osijek: Filozofski fakultet.

Vidović Bolt, Ivana. 2007. Metaforika zoonima u hrvatskoj frazeologiji. U: Kulturni bestijarij. Zagreb: Institut za etnologiju i folkloristiku - Hrvatska sveučilišna naklada. 403-424.

\section{RJEČNICI}

Belostenec, Ivan. 1740. Gazophylacium seu latino-illyricorum onomatum aerarium. Gazophylacium illyrico-latinum. Zagreb.

Fink Arsovski, Željka et al. 2006. Hrvatsko-slavenski rječnik poredbenih frazema. Zagreb: Knjigra. [HSRPF]

Moguš, Milan. 2001. Rječnik Marulićeve Judite. Zagreb: Institut za hrvatski jezik i jezikoslovlje.

\section{SUMMARY}

\section{ANIMAL IDIOMS IN OLD CROATIAN LITERATURE AND IN CONTEMPORARY CROATIAN LANGUAGE}

Article compares animal idioms in old Croatian literatury with animal idioms in contemporary Croatian language. The comparison will refer to idiom structure, grammar, lexic and meaning. The article deals escpecially with comparative animal idioms and comparative conjunctions in animal idioms such as kako, kano, kao, kot etc.

Key words: animal idioms, idiom structure, grammar, comparative animal idioms 
